\title{
A Note from the Editors
}

With this double issue devoted to the life and work of Paul Ricoeur we celebrate the journal's eighteenth year in print. We also take this opportunity to inaugurate a new name: the Journal of French Philosophy. The journal remains the official bulletin of the Société Américaine de Philosophie de Langue Française and retains its commitment to publishing scholarly articles in English and French on all aspects of French philosophy and philosophy in the Francophone world.

The Société Américaine de Philosophie de Langue Française is a member of the Association des Sociétés de Philosophie de Langue Française (ASPLF) created in 1937 by Léon Brunschvicg, Émile Bréhier, and André Lalande. The American branch was founded in 1988 by Colette Michael, then Professor of French at Northern Illinois University. Professor Michael had been approached some five years earlier by the president of the ASPLF who encouraged her to found an American branch of the Association, but was unable to do so at the time because of other commitments. When the invitation was renewed in 1987, Professor Michael happily agreed. The Société Américaine de Philosophie de Langue Française was officially inducted into the ASPLF one year later at its meeting in Dijon, France. At the Dijon meeting, Paul Ricouer volunteered to help Professor Michael create a refereed journal in the United States devoted to the work of the Society. At the time, Ricoeur was already teaching at the University of Chciago and hence was in the United States on a regular basis. In this way, the Bulletin 
de la Société Américaine de Philosophie de Langue Française was born.

Professor Michael remained the general editor of the Bulletin for twelve years. During this time, the journal published essays on a wide range of topics and figures, both historical and contemporary. For a short time, the Bulletin fell out of publication, but was revived with the help of Peter Caws who guest edited an issue on the philosophy of Simone de Beauvoir (vol. 13, no. 1) and helped get the journal back on a solid footing. Issues prior to volume thirteen are being newly archived on our website (search: Journal of French Philosophy).

In changing the name to the Journal of French Pbilosopby we do not depart from the earlier mission of the Bulletin, we only try to increase awareness of its existence and to reach as broad an audience as possible. We dedicate this issue and the rebirth of the journal to Colette Michael and Paul Ricoeur, with gratitude for their support and for all they have given both past and present to the intellectual life of the Society and French philosophy.

Diane Perpich

Daniel Smith

Editors 